\title{
Exploring Malaysian Corporate Leaders' Views of an Effective Board
}

\author{
Wan Fauziah Wan Yusoff ${ }^{1}$ \\ ${ }^{1}$ Faculty of Technology Management and Business, University Tun Hussein Onn Malaysia, Malaysia \\ Correspondence: Wan Fauziah Wan Yusoff, Faculty of Technology Management and Business, University Tun \\ Hussein Onn Malaysia, 86400 Parit Raja, Batu Pahat, Johor, Malaysia. E-mail: fauziahy@uthm.edu.my
}

Received: August 6, 2012 Accepted: September 12, 2012 Online Published: December 26, 2012

doi:10.5539/jms.v3n1p145 URL: http://dx.doi.org/10.5539/jms.v3n1p145

\begin{abstract}
The board of directors is acknowledged as one of the most important internal corporate governance structure. This paper reports a qualitative study on the characteristics of an effective board perceived by the Malaysian corporate leaders. The results are derived from semi structured interviews with 41 directors of top 100 Malaysian Public Listed Companies (PLCs). Four characteristics of an effective discovered in this study which comprise the board that has; (1) the right memberships, (2) the right culture; (3) clear roles and responsibilities; and (4) the right structures. This paper concludes that the behavioural aspect of the board in particular, the membership and culture of the board are found to be the most important components of an effective board. This has implication for those seeking to expand further research in corporate governance area. Finally, this paper provides a basis for characteristics of an effective board that can be applied by the Malaysian corporate governance regulators and policy-makers in enhancing Malaysian corporate governance policies.
\end{abstract}

Keywords: boards of directors, board effectiveness and corporate governance

\section{Introduction}

Board effectiveness studies emerged as a result of a number of corporate frauds, as well as an increase in public awareness about the importance of high standards of corporate governance. The important roles of board of director in corporate governance have also led to a number of studies. Such areas include; board composition, structure, roles and ownership structure. However, to date, no consistent evidence has yet been found on the characteristics of an effective board. Levrau and Van den Berghe (2007) argued that the inconsistent findings in board effectiveness research exist due to scholars' different backgrounds and their heterogeneous research purposes, as well as multiple approaches to determine the concept of effectiveness. Other researchers concluded that strategic decision-making, team working, and effective interaction with management are among the most reliable indicators of board effectiveness (e.g., Sonnedfeld, 2002; Huse, 2005, 2007; Schmidt \& Brauer, 2006).

In Malaysia the Asian financial crisis in 1997/1998 has provided added momentum to corporate governance reforms. Since then, various reforms were undertaken to improve corporate governance and board effectiveness in Malaysia. The most significant effort is the establishment of Malaysian Code of Corporate Governance (MCGG) in 2000. The MCCG codified the principles and best practices of good governance and described optimal corporate governance structures that apply to all Malaysian listed companies. The recommendation in the MCCG is aimed at improving board composition and increasing the efficiency and accountability of the boards to ensure independent decision-making. The establishment of the MCCG resulted in the revamp of Kuala Lumpur Stock Exchange (KLSE) Listing Requirement (LR) in 2002, specifically to address governance issues and to propose governance laws related to Malaysian listed companies. Such reforms include the requirement to increase the number of outside directors, restriction of multiple directorships, and the existence of financial expertise of board of directors of Malaysian PLCs. For instance, the KLSE Listing Requirement outlines that every listed company in Malaysia must appoint at least two independent directors, or have one-third of their boards members as independent directors, whichever is the higher. The MCCG as well as the KLSE LR however, did not specifically outline the characteristics of an effective board, in particular, the characteristics of board members. For example, there is no specific guideline that recommends the required size of Malaysian PLCs' boards. The MCCG has recommended that the size of the board should be determined based on the company's requirement, and the range of established laws of the corporation. Based on the above reviews this paper addresses the following research question: What are the key characteristics of an effective board of directors? 
To answer the above question, this paper explores and reports the key characteristics of an effective board perceived to be important within the context of top 100 Malaysian PLCs. This paper is structured into six sections. The next section discusses relevant literature on board's effectiveness, followed by research methodology in section three. The fourth section discusses data analysis process, and section five reports and discusses the research findings. This paper ends with a conclusion of the research in section six.

\section{Board Effectiveness: Evidence from Literature}

There is abundance of research that examines board effectiveness. However, there is no absolute board effectiveness measurement found in the literature. For the purpose of this paper, four characteristics of board effectiveness are reviewed, which are; board composition and structure, board membership, board culture, and board roles.

\subsection{Board Composition and Structure}

Early attempts to measure board effectiveness focused on quantitative measurements. Board effectiveness was measured as the relationship between various characteristics of board of directors (in particular board composition and structure) and various financial performance measurements such as Return on Assets (ROA), Return on Equity (ROE), Earnings Per Share (EPS) and Market Book Ratio (Tobin q). The literatures have identified board size, proportion of independent directors, and leadership structure as the key factors that influence the effectiveness of boards.

Many studies explored the relationship of the size of the board and firm performance, but yielded mixed results (e.g., Nicholson \& Kiel, 2003; Beiner et al., 2004; Dey \& Chauhan, 2009). Bhagat and Black (2002) argued that the mixed results are explained by the endogeneity of some factors in the board effectiveness model. For example, board size itself may be influenced by other governance factors such as board structure and board leadership (Colley et al., 2005). Inconclusive results were also found in studies of the dual role of chairman/CEO.

A number of studies discovered that role of chairman and CEO need to be separated because splitting the role provides the required check and balance that are necessary for an effective board (Fama \& Jensen, 1983; Zahra \& Pearce, 1989). At the same time it can dilute the power of the CEO and reduce the potential for the CEO to dominate the board (Finkelstein \& Mooney, 2003; Nadler et al., 2006). In contrast, in Australia Sharma (2004) revealed that when the chairman of the board is also the CEO, the board's monitoring role is weakened and the likelihood of fraud increases because of high tendency of the chairman to focus his/her interest than company's interest. Meanwhile, Rahman and Haniffa (2005) and Abdullah (2004) did not find any relationship between CEO duality and the performance of Malaysian firms. Likewise in Egypt, Elsayed (2007) found that CEO duality had no impact on corporate performance. The results show the impact of duality of roles of chairman/CEO on board and firm performance varies from one country to another. As both types of leadership structure are associated with similar effects on firm's performance, a firm needs to determine which structure relevant to its business operations.

\subsection{Board Memberships}

Through numerous changes that have occurred in the corporate environment during the last decade it was soon discovered that financial performance is no longer the only criteria to be taken into account when evaluating business effectiveness. Beginning year 2000 many scholars embarked studies in other aspects of board effectiveness and concluded that the overall component of the board including board behaviour in respect to strategic decision making, teamwork of board members and their interaction with management were the most reliable indicators of board effectiveness (e.g., Walt \& Ingley, 2001; Leblac, 2003; Finkelstein \& Mooney, 2003; Huse, 2005, 2007; Schmidt \& Brauer, 2006; Levrau \& Van den Berghe, 2007; Finegold, 2009). For example, two different studies by Leblanc (2003) and Berghe and Levrau (2004) discovered board memberships (includes the full panoply and balancing of all directors competencies and expertise) as the main components of an effective board followed by board structure and process. More importantly, they concluded that a board needs to have the "right" people who can shape the right structure, culture and process of the board. Consistent with this conclusion other researchers stated that personality characteristics of group members (including board members) are strong predictors of board effectiveness because individual board members bring their personality, moods and emotions to board interactions (Leblanc \& Gillies, 2005; Murphy \& McIntyre, 2007).

Due to the importance of the memberships of the boards of directors, in recent years institutional investors and stakeholders increasingly have pressured firms to appoint directors with diverse backgrounds in terms of their expertise and professionalism, to ensure that the board is protecting their interests. Hence, board memberships 
and their effectiveness to date have received major attentions in corporate governance research (e.g., Westphal \& Milton, 2001; Leblanc, 2003; Huse, 2007; Levrau \& Van den Berghe, 2007; Payne et al., 2009). For instance, a number of researchers found that increased board diversity led to better boards and governance (Pearce \& Zahra, 1991; Carver, 2002; Walt \& Ingley, 2003; Grosvold, Brammer \& Rayton, 2007). This can be explained because diversity allowed boards of directors to tap into a broader talent pool that can be used to reach good decision-making. Specifically, in Malaysia a study by Wan Fauziah and Armstrong (2012) revealed to be effective, companies should appoint board members who possess competencies that are relevant to their business.

\subsection{Board Culture}

Board culture is acknowledged as one of the major determinant of efficiency in organisations and corporate performance (e.g., Kotter \& Heskett, 1992; Nadler, 2006; Levrau \& Van den Berghe, 2007b; Hirota, Kubo \& Miyajima, 2008). Board culture can be defined as a set of values, beliefs and norms of behaviours shared by the board members that influence their preferences and behaviours (Kotter \& Heskett, 1992). For example, board that practicing openness enable the rest of board members to share their opinions and take part in decision-making (Nadler, 2006).

Numerous studies have reported that culture influences firm performance in various forms. From a theoretical analysis, Forbes and Milliken (1999) concluded that a good corporate culture is essential in building a cohesive board. Further, Finkelstein and Mooney (2003) discovered that some cultural components, such as conflict avoidance, teamwork, strategic involvement and comprehensiveness, are essential in determining effective boards. Other studies have found that good culture can enhance the communication flow and systems of control (Ginevicius \& Vaitkunaite, 2006), as well as cultivate the respect and high trust among board members (Barton \& Wong, 2006). A recent study by Wan Fauziah (2011) among Malaysian companies discovered culture have influence ROA of the firms. The reviews show that culture is one of the essential components in building an effective board and indirectly contributes to high firm performance.

\subsection{Board Roles}

The literature generally discusses three important roles of the board; control, service and strategic roles. First, controlling role reflect board of directors to have a legal duty to oversee companies' operations (Young et al., 2000; Bainbridge, 2002; Kemp, 2006). The dominant theory underlying the control role is agency theory, which initially became the prevailing school of thought in finance and economic research. This theory was concerned with resolving the agency problem that may arise when the interests of management differs from the interests of shareholders (Berle \& Means, 1932; Jensen \& Meckling, 1976; Fama \& Jensen, 1983). From an academic perspective, control roles can be seen as wide-ranging and include control of proxy mechanisms for the alignment of management's and shareholders' interests (Zahra \& Pearce, 1989; Dallas, 2001; David, 2006), removing managers who misused firm assets (Bozec, 2005), and monitoring the formation and implementation of strategic decisions (Johnson, et al.,1996; Belden, Fister \& Knapp, 2005; Summanen \& Lazareva, 2008).

Second is a service role. The service role primarily stems from resource dependency theory which views board members as 'boundary spanners' who secures important resources for firm survival (Pfeffer \& Salancik, 1978; Johnson et al., 1996; Hillman et al., 2000; Brown, 2007). For example, as the majority of external directors of large corporations were the top managers of other organisations, they had valuable information and expertise to contribute to strategic decision-making (Westphal \& Stern, 2007). To ensure that the board can perform the service role effectively, a number of scholars suggested that a firm needs to choose board members who possess particular backgrounds that are relevant to it business (Hillman et al., 2000; Conger \& Lawler, 2001; Hansel, 2003).

Lastly is the strategic role. The strategic role of board of directors has been acknowledged as important because it provides the opportunity to initiate strategic change that can mould the future of a firm (Ruigrok, Peck \& Keller, 2006). Particularly the strategic role is critical when a firm is in periods of environmental turbulence or declines in performance (Goodstein et al. 1994). To take active participation in strategic role it is suggested that board should be involved in a number of strategic roles such as: establishing a firm's strategic directions; oversee a firm's strategies, assess and monitor performance; as well as involved in the implementation of any strategies (Andrew, 1981; Tricker, 1984; Coulson-Thomas; 1993; Rindova, 1999).

The above reviews demonstrate that the roles of boards of directors are receiving growing attentions in corporate governance research. Nevertheless, it was argued that the roles of the board are often not well-defined because all of them have equal responsibilities to the board (Pearce \& Zahra, 1991; Brennan, 2006). As a result, there is always a gap of the roles of the board and the roles of management. To overcome such problem, it is suggested 
that a company should develop a written policy the clarify the roles of the board, the CEO and the company management (Carver \& Oliver, 2002; Cascio, 2004).

The brief reviews above show that despite extensive studies of board effectiveness the results have been generally inconclusive. Daily and Dalton (2003) argued that results were inconclusive because most board effectiveness studies rely on a 'black box', not observing what actually happens in the boardroom. As board effectiveness was influenced by a number of factors, this study explores wide ranges of interconnected structural and behavioural factors (e.g., trust, attitude, norms, and conduct) that determine the effectiveness of the board.

\section{Methodology}

As indicated above, vast majority of studies on boards of directors have relied upon quantitative data gathering technique which was mainly based on secondary data from annual reports; while a subset of board studies have also used questionnaires. Although these techniques offer the advantage to analyse the data in a consistent way, their access to process-oriented data is restricted (Daily et.al. 2003). One direction that the field needs to explore is the use of a more in-depth, qualitative approach involving the direct study of boards and contact with corporate directors. (Leblanc, 2003; Roberts et al., 2005).

To do so, this study used semi-structure interviews that enabled the respondents to provide their perceptions of an effective board in a holistic and meaningful ways (Yin, 2003). The questions were therefore exploratory and open-ended to reduce the possibility of the respondents providing responses driven by concepts identified by the researchers (Randall \& Fernandes, 1991). I interviewed 41 individuals. Within the sample, ten were the chairmen, 12 CEOs, 11 independent directors (all with the top 100 Malaysian PLCs' board). They were considered as "elite" because they are influential, prominent and well-informed, usually hold higher positions in the company and very familiar with the legal structures of their company (Marshall \& Rossman, 2006). In addition, I also interviewed eight representatives of Malaysian corporate governance associations, academicians, policy makers, bankers, etc.

\section{Data Analysis}

The interviews yielded a broad set of responses regarding criteria that constitute an effective corporate board, as perceived by the respondents. Data obtained from interviews were sorted and segmented into an excel spreadsheet. As recommended in literature (Miles and Huberman, 1994), I developed a coding list, based upon the literature on boards of directors and complemented the list with themes that emerged during data analysis. This resulted in a total of 12 qualitative codes (Table 1). The codes resemble as close as possible the respondents' responses.

In the next step, I grouped the responses that relate to similar themes and entered these grouping as "characteristics". Based on literature they were classified as four characteristics: (1) right memberships; (2) right culture; (3) clear roles; and (4) right structure. I also used a basic form of counting during the analysis process because it allowed me to more fully describe the variety of criteria that were cited during the interviews. The most frequently mentioned are ranked according to the total number of interviewees who spontaneously mentioned that component important to the effectiveness of the board. This was done so that a justified conclusion can be drawn from this study.

Table 1. Characteristics of effective board based on respondents' perceptions

\begin{tabular}{llcc}
\hline No & Characteristics & $\begin{array}{c}\text { Total } \\
\text { response }\end{array}$ & $\begin{array}{c}\text { Classification } \\
\text { number }\end{array}$ \\
\hline 1 & Diverse backgrounds of board members & 35 & 1 \\
2 & Competent board members & 30 & 1 \\
3 & Board has clear roles and responsibilities & 27 & 3 \\
4 & Cohesive board & 25 & 2 \\
5 & Board has good leadership by the chairman and the CEO & 23 & 1 \\
6 & Board has good relationships with the management & 22 & 2 \\
7 & Separate chairman and CEO & 16 & 4 \\
8 & Well defined roles of chairman/CEO & 15 & 3 \\
9 & Board is able to convert firm's strategy into action & 14 & 3 \\
10 & Board members share the same goals & 13 & 2 \\
11 & Board members show trust and tolerance to each other & 13 & 2 \\
12 & Board has high achievement & 11 & 2 \\
\hline
\end{tabular}


Note: Data drawn from the interviews with 41 respondents

1). Board memberships

2) Board culture

3) Board role

4) Board structure

\section{Findings and Discussion}

Research results regarding board effectiveness among Malaysian PLCs indicate that various aspects of boards influence their effectiveness. The findings presented in table 2 show four characteristics of boards of directors: board memberships; board culture; board roles; and board structure, were found to be important for the effectiveness of Malaysian PLCs' boards. Such results are consistent with previous studies by Walt and Ingley (2001), Leblanc (2003), Berghe and Levrau (2004), Levrau and Van den Berghe (2007) and Payne et al. (2009). Specifically, the memberships of the board are the most frequently reported by a great number of respondents. Closely followed board culture which expresses more intangible aspects of the board of directors resides on the second place, followed by the roles of the board. The less frequently mentioned characteristics refer to structure of the board.

Table 2. Four groups of characteristics of an effective board of directors respondents' perspectives

\begin{tabular}{lll}
\hline Group & characteristics & $\begin{array}{l}\text { Total frequency this characteristics } \\
\text { is reported }\end{array}$ \\
\hline 1 & Right board memberships & 88 \\
2 & Right culture & 84 \\
3 & Clear roles and responsibilities & 56 \\
4 & Right structure & 16 \\
\hline
\end{tabular}

First, this study demonstrated that board membership is the most essential component of board effectiveness. Specifically, it is indicated that three components of board memberships (diverse backgrounds of board members, competent board members, and good leadership of chairmen and CEOs) are important for the effectiveness of Malaysian PLCs' boards. Based on previous studies this study supports the conclusion that diverse backgrounds of board members lead to greater diversification of strategies (Carver, 2002; Walt \& Ingley, 2003; Brammer \& Rayton, 2007). This can be explained because boards of directors are more effective if the boards consist of members who are competent, have relevant knowledge and broader experience. Having these competencies enables them to bring fresh ideas and insights for effective board decision-making.

Second, the results also discovered five cultural components (cohesive boards, good relationships with management, sharing the same goal, showing trust and tolerance to each other and high achievement) are important for the effectiveness of Malaysian PLCs' boards. Specifically, the project confirms previous studies (such as Finkelstein \& Mooney, 2003; Ginevicius \& Vaitkunaite, 2006; Barton \& Wong, 2006), which indicate that cohesive boards, respect and high trust among board members are important components of strong board culture that can enhance communication flow. In addition, consistent with previous studies (Kotter \& Heskett, 1992; Levrau \& Van den Berghe, 2007) it is also revealed that having a positive culture is an important instrument of internal control of a company in ensuring high standards of corporate governance. In accordance to Barton and Wong (2006) and Nadler (2006), having the above components enable Malaysian PLCs' board members to reach consensus in decision-making. Therefore, the conclusion establishing a strong board culture is important for the enhancement of a company's future.

Third, the results regarding the role of boards of directors is in agreement with previous scholars who argued that board effectiveness also relies on the individual roles of boards of directors (e.g., Conger \& Lawler, 2001; Walt and Ingley, 2001; Epstein \& Roy, 2004). For example, based on Conger and Lawler (2001) this study concludes that boards' abilities to perform their roles (including scanning for opportunities and threats, providing constructive feedback and guidance to the CEO, extending their networks and providing external sources of knowledge) is likely to contribute to the enhancement of firm performance. 
More importantly, this current research has found that the roles of boards of directors and company management need to be clearly defined. Based on Cascio (2004) and Carver and Oliver (2002), I argue that clearly defined roles of boards of directors and company management are required to avoid overlapping of roles. In addition, this study confirms with previous study that Malaysian PLCs' boards should be focused more on strategic roles, including establishing a firm's strategic directions, overseeing a firm's strategies and assessing and involving strategic implementation (Andrew, 1981; Tricker, 1984; Rindova, 1999; Carpenter \& Westphal, 2001). Specifically, strategic role is needed to enable the board to deal with massive transformation in a global economy (Hillman et al., 2001; Ingley \& Walt, 2003). More importantly, a strategic role is crucial for firms' future survival, especially when a firm's performance declines because of economic turbulence (Goodstein et al., 1994; Ruigrok et al. 2006; Langton \& Robbins, 2007). Therefore, it is suggested that to be effective, boards of directors' roles need to be defined clearly and focused on strategic roles.

Finally, it was also found that the effectiveness of Malaysian PLCs' boards relies on board structures. Notably, the most important components of board structure for the effectiveness of Malaysian PLCs' boards are separation of chairmen/CEOs roles. In agreement with Fama and Jensen (1983) and Nadler et al., (2006), this study concludes that separation of the roles of chairmen and CEOs of Malaysian PLCs is necessary to prevent any conflict of interest, especially when a person holding both positions is a prominent individual. At the same time, separation of roles can reduce the centralisation of power that can lead one person dominate the board (Finkelstein \& Mooney, 2003; Nadler et al., 2006). Therefore, that separation of chairman and CEO enables boards to perform their monitoring role more effectively.

\section{Conclusion}

In summary, the major purpose of this study was to explore Malaysian corporate leaders perceived about an effective board. Although board effectiveness is frequently studied in academic research, in Malaysian scholars traditionally focused on limited number of characteristics particularly board size, the proportion of the NEDs and leadership structure. In contrast, this study explores a wide variety of characteristics of effective board. This study revealed four characteristics of effective board that are essential for Malaysian PLCs include (1) the right memberships including diverse and competent members (2) the right cultures; (3) clear roles and responsibilities; and (4) the right structure, particularly separation of roles of the chairman and CEO.

As much of the existing board effectiveness research reported in the literature focuses on developed countries' corporations and governance, the present study, firstly, contributes to this body of knowledge by providing evidence using primary data from Malaysia. In doing so, the results of this study add to the knowledge base for countries with developing economies. Arguably, the latter country has a high concentration of ownership, less transparent and weaker corporate governance structures than those in developed economies such as the US, UK and Australia.

Secondly from a practical perspective, this study provides feedback to the Malaysian corporate governance regulators and policy-makers (e.g., Bursa Malaysia, Securities Commission and MCCG) to assist in developing policies that support the importance of desirable characteristics of the board. Nevertheless, the results are limited to the information obtained from respondents' perception on the issues that is studied. A limited number of respondents may limit generalisability of the results. However, these provide a strong basis for future research by providing specific variables that can be explored further.

\section{References}

Abdullah, S, N. (2004). Board composition, CEO duality and performance among Malaysian listed companies. Corporate Governance International Journal of Business in Society, 4, 47-61. http://dx.doi.org/10.1108/14720700410558871

Allan, C. A. L. (2004). The impact of corporate governance practices on firms' financial performance. ASEAN Economic Bulletin, 21(3), 308-318. http://dx.doi.org/10.1355/AE21-3D

Andrew, K. R. (1981). Corporate strategy as a vital function of the board. Harvard Business Review, 59(11), 174-184.

Bainbridge, S. M. (2002). Why a board? Group decision-making in corporate Governance. SSRN eLibrary. Retrieved from http://ssrn.com/paper=266683

Barton, D., \& Wong, S. C. Y. (2006). Improving board performance in emerging markets. McKinsey Quarterly, $1(1), 74-83$. 
Beiner, S., Drobetz, W., Schmid, F., \& Zimmermann, H. (2004). Is board size an independent corporate governance mechanism? Kyklos, 57(3), 327-356. http://dx.doi.org/10.1111/j.0023-5962.2004.00257.x

Belden, S., Fister, T., \& Knapp, B. O. B. (2005). Dividends and directors: Do outsiders reduce agency costs? Blackwell-synergy. http://www.blackwell-synergy.com/doi/abs/10.1111/j.0045-3609.2005.00009.x.

Berghe, L. A., \& Levrau, A. (2004). Evaluating boards of directors: What constitutes a good corporate board? Blackwell-synergy.

Retrieved

from http://www.blackwell-synergy.com/doi/abs/10.1111/j.1467-8683.2004.00387.x.

Berle, A. A. J., \& Means, G. C. (1932). The modern corporation and private property. New York: MacMillan.

Bhagat, S., \& Black, B. S. (2002). The uncertain relationship between board composition and firm performance. SSRN eLibrary . Retrieved from http://ssrn.com/paper=11417.

Bozec, R. (2005). Boards of directors, market discipline and firm performance. Journal of Business Finance \& Accounting, 32, 1921-1960. http://dx.doi.org/10.1111/j.0306-686X.2005.00652.x

Brennan, N. (2006). Boards of directors and firm performance: Is there an expectations gap? Corporate Governance: An International Review, 14(6), 577-593. http://dx.doi.org/10.1111/j.1467-8683.2006.00534.x

Brown, W. A. (2007). Board development practices and competent board members: Implications for performance. Nonprofit Management \& Leadership, 17(3), 301-317. http://dx.doi.org/10.1002/nml.151

Bursa Malaysia. (2002). KLSE Listing Requirement. Retrieved from http://www.klse.com.my/website/bm/rules_and_regulations/listing_requirements/downloads/LR_MBSB_2 8Dec06.pdf.

Carpenter, M. A., \& Westphal, J. D. (2001). The strategic context of external network ties: Examining the impact of director appointments on board involvement in strategic decision making. SSRN eLibrary. Retrieved from http://ssrn.com/paper=176428.

Carver, J., \& Oliver, C. (2002). Corporate boards that create value. San Francisco: Jossey-Bass A Wiley Company.

Cascio, W. F. (2004). Board governance: A social systems perspective. Academy of Management Executive, 18(1), 97-100. http://dx.doi.org/10.5465/AME.2004.12689560

Colley, J. L., Doyle, J., Dogan, G. L., \& Stettinius, W. (2005). What is corporate governance? New York: Mc Graw Hill.

Conger, J. A., \& Lawler, E. (2001). Building a high-performing board: How to choose the right members. Business Strategy Review, 12(3), 11-19. http://dx.doi.org/10.1111/1467-8616.00179

Coulsin-Thomas. (1993). Developing directors - building an effective boardroom team. Berkshire, England: McGraw-Hill Book Company.

Daily, C. M., Dalton, D. R., \& Cannella, A. (2003). Corporate governance: Decades of dialogue and data. Academic Management Review, 28(3), 371-382.

Dallas, L. L. (2001). Developments in USA board of directors and the multiple roles of corporate board. Law and economic research paper, 1 .

David, T. (2006). The role of the non-executive director: A personal view. Corporate Governance, 6(1), 64-68. http://dx.doi.org/10.1108/14720700610649463

Dey, D. K., \& Chauhan, Y. K. (2009). Board composition and performance in Indian firms: A comparison. ICFAI Journal of Corporate Governance, 8(2), 7-19.

Elsayed, K. (2007). Does CEO duality really affect corporate performance? Corporate Governance: An International Review, 15(6), 1203-1214. http://dx.doi.org/10.1111/j.1467-8683.2007.00641.x

Fama, E., \& Jensen, M. (1983). The separation of ownership and control. Journal of Law and Economics, 26, 301-325. http://dx.doi.org/10.1086/467037

Finegold, D., Benson, G., \& Hecht, D. (2007). Corporate boards and company performance: Review of research in light of recent reforms. Corporate Boards and Company Performance, 15(5), 856-878.

Finkelstein, S., \& Mooney, A. C. (2003). Not the usual suspects: How to use board process to make boards better. Academy of Management Executive, 17(2), 101-113. http://dx.doi.org/10.5465/AME.2003.10025204 
Forbes, D. P., \& Milliken, F. J. (1999). Cognition and corporate governance: Understanding boards of directors as strategic decision groups. Academic management Review, 24(3), 489-505.

Ginevicius, R., \& Vaitkunaite, V. (2006). Analysis of organisational culture dimensions impacting performance Journal of Business Economics \& Management, 7(4), 201-211.

Goodstein, J., Gautham, K., \& Boeker, W. (1994). The effects of board size, diversity on strategic change. Strategic Management Journal, 15(3), 241-250. http://dx.doi.org/10.1002/smj.4250150305

Grosvold, J., Brammer, S., \& Rayton, B. (2007). Board diversity in the United Kingdom and Norway: An exploratory analysis. Business Ethics. A European Review, 16(4), 344-357. http://dx.doi.org/10.1111/j.1467-8608.2007.00508.x

Gul, F., \& Tsui, J. S. L. (2004). The Governance of East Asian corporation: Post Asian financial crisis. New York, USA: Palgrave McMillan.

Haniffa, R. M., \& Cooke, T. E. (2002). Culture, corporate governance and disclosure in Malaysian corporations. Abacus, 38(3), 317-349. http://dx.doi.org/10.1111/1467-6281.00112

Haniffa, R. M., \& Hudaib, M. (2006). Corporate governance structure and performance of Malaysian listed companies. Journal of Business Finance and Accounting, 33(7), 1034-1062. http://dx.doi.org/10.1111/j.1468-5957.2006.00594.x

Hansell, C. (2003). The road to good corporate governance. Camagazine, December, 30-33.

Hillman, A. J., Canella, A. A., \& Paetzold, R. L. (2000). The resource dependency role of corporate governance directors: Strategic adaptation of board composition in response to environmental change. Journal of Management Studies, 37(2), 0022-2380.

Hirota, S., Kubo, K., \& Miyajima, H. (2008). Does corporate culture matter? Evidence from Japan. SSRN eLibrary. Retrieved from http://ssrn.com/paper=1118196.

Huse, M. (2005). Accountability and creating accountability: A framework for exploring behavioural perspectives of corporate governance. British Journal of Management, 16, 65-79. http://dx.doi.org/10.1111/j.1467-8551.2005.00448.x

Jensen, M. C., \& Meckling, W. (1976). Theory of the firm: Managerial behaviour, agency costs and ownership $\begin{array}{lllll}\text { structure. Journal of } & \text { Financial } & \text { Economics, } & 3(4), & 305-360 .\end{array}$ http://dx.doi.org/10.1016/0304-405X(76)90026-X

Johnson, J. L., Daily, C. M., \& Ellastrad, A. E. (1996). Boards of directors: A review and research agenda. Journal of Management. Retrieved from http://www.findarticles.com/p/articles/mi_m4256/is_n3_v22/ai_18764055.

Kasipillai, J. (2005). Insight into corporate governance in Malaysia. In N. Balasubramaniam (Ed.), An international perspective on corporate boards and corporate governance. Kuala Lumpur: Malaysian Insurance Institute.

Kemp, S. (2006). In the driver's seat or rubber stamp? The role of the board in providing strategic guidance in Australian Boardrooms. Journal of Management Decision, 44(1), 56-73. http://dx.doi.org/10.1108/00251740610641463

Kotter, J. P., \& Heskett, J. L. (1992). Corporate culture and performance. New York: The Free Press.

Leblanc, R. (2003). Board of directors: An inside view. ProQuest digital dissertation (AAT NQ82802). Retrieved from

http://0-proquest.umi.com.library.vu.edu.au/pqdweb?did=764811041\&sid=11\&Fmt=2\&clientId=20884\&R $\mathrm{QT}=309 \& \mathrm{VName}=\mathrm{PQD}$

Leblanc, R., \& Gillies, J. (2005). Inside the board room: How boards really work and the coming revolution in corporate governance. Ontario Canada: John Wiley \& Son.

Levrau, A., \& Van den Berghe, L. A. A. (2007). Corporate governance and board effectiveness: Beyond Formalism. ICFAI Journal of Corporate Governance, 6(4), 58-85.

Malaysian Code of Corporate Governance. (2000). Retrieved from http:///.www.micg.org.my

Marshall, C., \& Rossman, G. B. (2006). Designing qualitative research (4th ed.). Sage Publication. 
McGee, R. W. (2008). Corporate governance in Asia: Eight case studies. Working Paper School of Accounting, Florida International University, 38. Retrieved from http://ssrn.com/abstract=1081954.

Miles, M. B., \& Huberman, A. M. (1994). Qualitative data analysis: An expended sourcebook (2th ed.). Thousand Oaks, California: Sage Publications.

Nadler, D. A. (2006). The role of leaders in shaping board culture. In N. David A, B. A. Behan \& M. B. Nadler (Eds.), Building better boards: A blueprint for effective governance (pp. 104-125). San Francisco: Jossey-bass.

Nicholson, G. J., \& Kiel, G. C. (2004). A framework for diagnosing board effectiveness. Corporate Governance: An International Review, 12(4), 442-460. http://dx.doi.org/10.1111/j.1467-8683.2004.00386.x

Payne, G. T., Benson, G. S., \& Finegold, D. L. (2009). Corporate board attributes, team effectiveness and financial performance. Journal of Management Studies, 46(4), 704-731. http://dx.doi.org/10.1111/j.1467-6486.2008.00819.x

Pearce, J. A., \& Zahra, S. A. (1991). The relative power of CEOs and boards of directors: Associations with

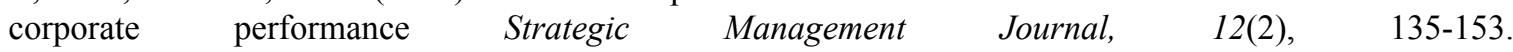
http://dx.doi.org/10.1002/smj.4250120205

Pfeffer, J., \& Salancik, G. R. (1978). The external control of organisations: A resource dependence perspective. New York: Harper \& Row.

Rahman, R. A., \& Haniffa, R. M. (2005). The effect of role duality on corporate performance in Malaysia. Corporate Ownership \& Control, 2(2), 40-47.

Rahman, R. A., \& Mohamed Ali, F. H. (2006). Board, audit committee, culture and earnings management: $\begin{array}{lllll}\text { Malaysian evidence. Managerial Auditing Journal, 21(7), 783-804. } & \text {. }\end{array}$ http://dx.doi.org/10.1108/02686900610680549

Randall, D. M, \& Fernandes, M. F. (1991). The social desirability response bias in ethic research. Journal of Business Ethics, 10, 805-817. http://dx.doi.org/10.1007/BF00383696

Rindova, V. P. (1999). What corporate boards have to do with strategy: A cognitive perspective. Journal of Management Studies, 36(7), 953-975. http://dx.doi.org/10.1111/1467-6486.00165

Roberts, J., McNulty, T., \& Stiles, P. (2005). Beyond agency conceptions of the work of the non-executive director: Creating accountability in the boardroom. British Journal of Management, 16, 5-26. http://dx.doi.org/10.1111/j.1467-8551.2005.00444.x

Ruigrok, W., Peck, S. I., \& Keller, H. (2006). Board characteristics and involvement in strategic decision making: Evidence from Swiss companies. Journal of Management Studies, 43(5), 1201-1226. http://dx.doi.org/10.1111/j.1467-6486.2006.00634.x

Salleh, Z., Steward, J., \& Stuard, M. (2005). The impact of board composition and ethnicity on audit quality: Evidence from Malaysia. Retrieved from http://www.quensland.acc.edu.au.

Schmid, M. M., \& Zimmermann, H. (2005). Should chairman and CEO be separated? leadership structure and firm performance in Switzerland SSRN eLibrary. Retrieved from http://ssrn.com/paper=696381.

Schmidt, S. L., \& Brauer, M. (2006). Strategic Governance: How to assess board effectiveness in guiding strategy execution. Corporate Governance: An International Review, 14(1), 13-22. http://dx.doi.org/10.1111/j.1467-8683.2006.00480.x

Sharma, V. D. (2004). Board of director characteristics, institutional ownership, and fraud: Evidence from Australia. Auditing, 23(2), 107-119.

Sonnenfeld, J. A. (2002). What makes great boards Great. Harvard Business Review, 8(3).

Summanen, T., \& Lazareva, O. (2008). Emerging boards of directors: Board behaviour, functions and firm performance. SSRN eLibrary. Retrieved from http://ssrn.com/paper=1102473.

Walt, N. V., \& Ingley, C. B. (2001). Evaluating board effectiveness: The changing context of strategic governance. Journal of Change Management, l(4), 313-331. http://dx.doi.org/10.1080/738552741

Wan Fauziah, W. Y., \& Armstrong, A. (2012). What competencies should directors possess? Malaysian Perspective. International Journal of Business and Management, 7(2), 142-1149. 
Wan Fauziah, W. Y. (2011). Does organizational culture influence firm performance in Malaysia? Zenith International Journal of Multidisciplinary Research, 1(3), 1-12.

Westphal, J. D., \& Milton, L. P. (2000). How experience and network ties affect the influence of demographic minorities on corporate boards. Administrative Science Quarterly, 45. http://dx.doi.org/10.2307/2667075

Westphal, J. D., \& Stern, I. (2007). Flattery will get you everywhere: How irrigation, boardroom behaviour, and demographic minority status affect additional board appointments at US companies. Academy of Management Journal, 50, 267-288. http://dx.doi.org/10.5465/AMJ.2007.24634434

Young, G. J., Stedham, Y., \& Beekun, R. I. (2000). Boards of directors and the adoption of a CEO performance evaluation process: Agency - and institutional - theory perspectives. Journal of Management Studies, 37(2), 45-56. http://dx.doi.org/10.1111/1467-6486.00181

Yusoff, W. (2006). Board composition, audit committee and timeline of corporate financial reports in Malaysia. Journal of Corporate Ownership \& Control, 4(2), 33-45.

Yusoff, W. (2007). Board, governance and value creation. Cambridge, UK: Cambridge University Press.

Zahra, S. A., \& Pearce, J. A. (1989). Board of directors and corporate financial performance. Journal of management, 15(2), 291-334. http://dx.doi.org/10.1177/014920638901500208 